when they flew from one end of the lake to the other the Little Gull fell 100 to 200 yards behind the Bonaparte's Gull. This may be only when the birds are flying to escape danger. Probably in migration flight and as we saw in feeding flight, the Little Gull had no difficulty in keeping up with the flock of Bonaparte's that it must have arrived with.

Special thanks go to Bob Luterback, the person who first spotted the bird and my co-identifier. Thanks are also due Jim Jowsey, Margaret Belcher, Frank Brazier and, especially George Ledingham for confirming the identification.

'GODFREY, W. E. 1966. The birds of Canada. Nat. Mus. Canada Bull. 203. $428 \mathrm{pp}$.

${ }^{2}$ NERO, R. W. 1963. Birds of the Lake Athabasca region, Saskatchewan. Sask. Nat. Hist. Soc Spec. Pub. 5. 143 pp.

3PETERSON, R. T. 1947. A field guide to the birds. Houghton-Mifflin, Boston. 290 pp.

${ }^{4}$ ROBBINS, C. S., B. BRUUN and H. S. ZIM. 1966. Birds of North America. A guide to field identification. Golden Press, New York. 340 pp.

Editor's Note: A few Little Gulls were found nesting in Ontario in 1962 !

\section{HOUSE FINCHES SIGHTED IN REGINA}

\author{
by FRED G. BARD*
}

At approximately 1:45 p.m. on April 26, 1973, my wife, Phyllis, called me outside to see three birds which she was sure she hadn't seen in Regina before. To my surprise, they were House Finches - all three rosycoloured males. They were feeding in our neighbour's adjoining backyard on the ground and later on the buds of seedling plum trees. They afforded us an excellent view as they fed for about 10 minutes. In recent years during several rather lengthy visits to New Mexico and California, we had

*633 Broadway Ave.,

Regina, Saskatchewan. become familiar with House Finch which are common residents ther They could only be confused with th Purple Finch which was a frequer visitor to our neighbourhood th spring but the song and call notes ar quite distinctive from those of th Purple Finch. As well, the reddis colouring on the House Finch is a di ferent shade, being more scarlet tha the wine red or purplish red of th Purple Finch which also has a ligh cheek streak. However, to make ce tain of the identification we were $a b$ to compare field marks with the aid Robbins' field guide, "Birds of Nort America" with the birds before us. $\mathrm{Th}$ brown streaking of the breast, side and flanks confirmed the ider tification. Suddenly, they flew aw: and, although I placed mixed seeds the area in hopes of attracting the back, they were not seen again.

L. G. Saunders reported seeing male House Finch at Saskatoon, O tober 15, 1959 (Blue Jay, Decemb 1959:158), but because not all fiel marks were noted at the time th record has not generally been accep ted. Note that this species has not at peared on the official list of Saska chewan birds.

W. Earl Godfrey in "Birds Canada", 1966, describes their rang as follows: "Southwestern and centra southern British Columbia, Idah Wyoming, and western Nebraska sout to southern Mexico." Included in th range description for Canada is th notation quote, "casual in soutl western Alberta (Jasper Park May 2 1944).’'

\section{A FURTHER SIGHTING OF WANDERING TATTLERS IN ALBERTA}

\author{
by E. OTTO HOHN*
}

The second edition of Birds o Alberta ${ }^{1}$ states that Wandering Tattler have been recorded in the province o three occasions, each report involvin a single bird. Professor W. Ray Sal 